\title{
PERANCANGAN MEDIA INFORMASI BERBASIS VIDEO TENTANG KOLEKSI ACTION FIGURE
}

\author{
Briantito Adiwena ${ }^{1}$ \\ Benny Rahmawan Noviadji ${ }^{2}$ \\ Daniel Andi Santoso 3 \\ Institut Informatika Indonesia, Surabaya \\ briantito@ikado.ac.id
}

\begin{abstract}
Abstrak
Mengoleksi action figure bukan hanya bentuk kesenangan semata, namun juga sudah menjadi sebuah gaya hidup di masyarakat Indonesia saat ini, khususnya di kota besar seperti Surabaya. Kegiatan ini juga terkadang masih dipandang sebagai sikap kekanak-kanakan oleh sebagian masyarakat, namun tidak banyak yang mengetahui bahwa mengoleksi action figure juga dapat menjadi aset investasi. Penelitian ini ditujukan kepada masyarakat untuk memberikan informasi seputar action figure yang jarang diketahui oleh masyarakat umum, khususnya untuk masyarakat yang ingin memulai mengoleksi action figure. Melalui media video yang ditayangkan di YouTube, penonton mendapatkan informasi seputar action figure yang dikemas dalam bentuk konten berseri.

Penelitian ini menggunakan metode wawancara dengan para kolektor dan penjual action figure dan diperdalam lagi dengan penyebaran kuesioner yang ditujukan kepada komunitas pecinta action figure yang ada di kota Surabaya. Data yang diperoleh digunakan sebagai dasar untuk menyusun alur tema video, penentuan gaya sinematografi dan proses penyusunan naskah narasi.

Hasil karya video yang bernama AIGO ini diupload melalui media Youtube. Untuk musim pertama ini terdapat 4 video dengan durasi 5-6 menit yang menjelaskan terkait sejarah action figure, cara merawat action figure, jenis-jenis action figure yang memiliki nilai investasi, dan bagaimana membedakan action figure yang asli dengan yang palsu. Karya ini juga didukung dengan media penunjang pemasaran digital yang berupa video animasi, akun resmi di instagram, tiktok serta media penunjang pemasaran lainnya yang berupa kaos suvenir, stiker, totebag, hingga gantungan kunci.
\end{abstract}

Kata kunci: action figure, videografi, vlog, youtube 


\begin{abstract}
Collecting action figures is not only a form of pleasure, but has also become a lifestyle in Indonesian society today, especially in big cities like Surabaya. This activity is also sometimes still seen as childish by some people, but not many know that collecting action figures can also be an investment asset. This research is aimed at the public to provide information about action figures that are rarely known by the general public, especially for people who want to start collecting action figures. Through video media that is shown on YouTube, viewers get information about action figures packaged in the form of serial content.

This study uses interviews with collectors and sellers of action figures and deepened by distributing questionnaires addressed to the community of action figure lovers in the city of Surabaya. The data obtained used as a basis for compiling the plot of the video theme, determining the cinematographic style and the process of compiling a narrative script.

The video work called AIGO uploaded via Youtube media. For the first season, have 4 videos with a duration of 5-6 minutes that explain the history of action figures, how to care for action figures, types of action figures that have investment value, and how to distinguish real action figures from fake ones. This work is also supported by digital marketing support media in the form of animated videos, official accounts on Instagram, Tiktok and other marketing support media in the form of souvenir t-shirts, stickers, tote bags, and key chains..
\end{abstract}

Key words: action figures, videography, vlogs, youtube.

\title{
PENDAHULUAN
}

Di era informasi yang serba cepat ini, tidak sulit bagi setiap orang untuk mempelajari hal-hal baru dalam hidupnya. Hal ini menyebabkan muncul banyaknya minat yang beragam didalam sebuah lingkungan masyarakat, salah satunya adalah tren untuk mengoleksi action figure. Action figure merupakan jenis mainan figur karakter dengan ukuran terskala yang memiliki artikulasi pada bagian sendi-sendinya sehingga dapat digerakkan. Dengan adanya lisensi yang diberikan oleh studio film atau pencipta karakter kepada perusahaan-perusahaan yang bergerak di bisnis action figure, maka perusahaan-perusahaan ini secara resmi dapat menciptakan action figure yang memiliki kemiripan dengan karakter aslinya. Hal inilah yang menjadi daya tarik bagi para kolektor untuk berlomba-lomba untuk memiliki action figure. 
Sebagian masyarakat memang ada yang berpendapat bahwa mengoleksi action figure tidak jauh beda dengan mengoleksi mainan pada umumnya, sehingga stigma yang timbul di masyarakat cenderung menganggap bahwa mengoleksi action figure tidak lebih sebagai hobi yang kekanak-kanak. Namun tidak banyak yang mengerti bahwa action figure tertentu dapat menjadi aset investasi yang cukup diminati oleh para kolektor. Dikutip dari situs Action Figure Fury (2014), pada dasarnya action figure adalah miniatur dari sosok-sosok populer. Namun, sama dengan barang lainnya yang beredar di pasar, barang ini akan bernilai rendah bila diproduksi secara massal. Maka semakin langka sebuah action figure dibuat dan semakin sulit ditemukan, maka semakin mahal harganya. Hal inilah yang menjadi salah satu sebab mengapa action figure dapat menjadi sebuah aset investasi yang cukup diminati.

Dengan semakin tingginya minat masyarakat terhadap action figure maka semakin besar pula masalah yang akan timbul. Hal yang sudah terlihat saat ini adalah beredarnya action figure palsu yang hampir menyerupai action figure asli yang dikeluarkan merek-merek pemegang lisensi. Action figure palsu yang sering disebut dengan istilah bootleg ini pun telah beredar bersama dengan yang aslinya dan kehadirannya tentu akan merugikan para kolektor. Mengutip dari situs Medcom (2015), ada beberapa hal yang dapat diperhatikan untuk membedakan action figure asli dengan palsu, mulai dari memperhatikan wujud kemasan, detail fisik action figure, harga yang ditawarkan, hingga pemilihan tempat dimana akan membeli action figure. Hal yang patut disayangkan adalah minimnya informasiinformasi tersebut tidak dapat tersampaikan secara luas dikarenakan informasi seperti itu masih dalam bentuk artikel maupun tulisan didalam forum. Hal ini tentunya menyulitkan para kolektor pemula yang cenderung mencari informasi melalui media visual salah satunya adalah video.

Menurut data situs Databoks (2021) menyatakan bahwa pada tahun 2020 masyarakat Indonesia rata-rata setiap hari waktu menggunakan internet melalui perangkat apapun: 7 jam, 59 menit. Dan platform media sosial yang paling banyak digunakan adalah YouTube, dimana sebanyak $88 \%$ total jumlah penduduk Indonesia pengguna YouTube. Maka dari itu perancangan yang akan dilakukan akan fokus kepada masalah penyampaian informasi terkait action figure yang dapat 
dikemas dalam bentuk video dan bagaimana menyampaikan informasi tersebut dengan tampilan yang tidak terkesan monoton dan membosankan.

\section{KAJIAN TEORI}

\section{Action Figure}

Action figure adalah sejenis model miniatur trimatra yang memuat visualisasi karakter secara detail. Pada umumnya, action figure merupakan visualisasi dari karakter yang populer di masyarakat, yang berasal dari film, komik, video game atau acara televisi. Terbuat dari lastik, karet dan berbagai jenis material komposit. Action figure dibuat untuk menggambarkan sosok tokoh populer secara lengkap, meliputi kostum, gestur fisik, atribut, asesoris dan pekerjaannya yang membuat ia terkenal dan layak dikenang sebagai legendaris atau orang yang penting. Pada saat ini terdapat hampir 40.000 action figure dengan lebih dari 700 merek yang dipasarkan di Indonesia yang berasal dari beberapa negara industri maju (Putra, 2010).

\section{Video}

Video merupakan media yang digunakan untuk merekam suatu momen atau kejadian yang dikemas dalam sebuah sajian gambar bergerak beserta audio yang dapat ditonton. Video dapat dipergunakan untuk berbagai kepentingan seperti hiburan, edukasi, komersial dan non-komersial. Seorang videografer juga harus dapat mengolah pencahayaan untuk mendukung konsep yang akan digunakan untuk menampilkan citra visual yang akan ditampilkan.

Menurut Widada (2019), beberapa hal yang perlu diperhatikan dalam proses pembuatan video, yang pertama adalah aspect ratio. Rasio aspek adalah hubungan lebar gambar video yang dibandingkan dengan tinggi badannya. Aspek yang umum digunakan adalah 4:3 yang juga dikenal dengan 1.33:1 atau fullscreen, dan 16:9 yang juga dikenal dengan 1.78:1 atau layar lebar. Pengetahuan akan rasio aspek ini akan dapat memaksimalkan penyajian video di media penayangannya dan mempengaruhi jenis lensa yang akan digunakan.

Beranjak dari rasio aspek, hal berikutnya yang perlu diperhatikan adalah framing atau bidang pandangan. Bidang pandang merupakan langkah pengambilan 
gambar yang memperhitungkan luas sudut pandang antara objek utama dan objek lainnya yang berhubungan dengan latar belakang (Widada, 2019). Perbedaan rasio aspek tentunya akan mempengaruhi luasan sudut pandang dan akan mempengaruhi faktor-faktor lainnya, seperti pencahayaan, angle, dan teknik pengambilan gambarnya.

\section{YouTube}

YouTube merupakan situs berbagi video terbesar dan terpopuler di dunia saat ini. Situs ini memfasilitasi penggunanya untuk mengunggah video maupun menyiarkan video secara langsung yang dapat ditonton oleh pengguna lain diseluruh dunia secara gratis. Mengutip dari Setiadi (2019) YouTube telah memiliki lebih dari 1 miliar pengguna, yang berarti hampir sepertiga dari seluruh pengguna internet. Mayoitas pengguna berusia 18-34 tahun dan lebih dari 70\% waktu menonton video di YouTube berasal dari perangkat seluler.

YouTube dalam masa pandemi ini menjadi salah satu media informasi dan hiburan yang sering dikunjungi. Berdasarkan data statistik, media sosial YouTube adalah salah satu platform yang menduduki posisi paling populer yang di Indonesia dimulai dari usia 16 hingga 64 tahun. Persentase penggunaan media sosial YouTube mencapai $88 \%$ dan disusul oleh Whatsapp sebesar $84 \%$, Facebook $82 \%$ dan Instagram 79\% (Junawan, 2020).

\section{METODE PENELITIAN}

Penelitian ini merupakan penelitian yang menggunakan kuesioner sebagai instrumen penelitian. Kuesioner merupakan lembaran yang berisi beberapa pertanyaan dalam struktur yang baku (Priyono, 2008). Kuesioner ini digunakan untuk mendapatkan data awal terkait variabel apa saja yang menjadi alasan seseorang tertarik, menyukai, dan mengoleksi action figure.

Penelitian ini juga menggunakan metode wawancara untuk mendapatkan informasi yang tidak dapat diperoleh melalui observasi maupun kuesioner. Metode wawancara digunakan untuk menangkap persepsi, pikiran, pendapat, perasaan responden terhadap suatu gejala, peristiwa, fakta atau realita (Raco, 2010). Sehingga dengan metode ini responden akan membagikan informasi lebih 
mendalam terkait action figure, bagaimana cara merawatnya dan bagaimana melihat peluang nilai investasi yang akan timbul pada beberapa jenis action figure tertentu.

Perancangan ini bertujuan untuk memberikan informasi dan edukasi seputar action figure melalui kanal YouTube sebagai media penyebarannya. Video yang disajikan dikemas dengan bentuk konten yang didukung dengan beberapa data infografis untuk mempermudah proses penyampaian informasi. Data terkait infografis maupun tema yang akan dibahas didapat dengan metode kuesioner yang disebar ke komunitas, pelaku/kolektor hingga pedagang. Selain itu juga dilakukan wawancara yang ditujukan kepada pelaku/kolektor dan pedagang untuk mendapatkan informasi mendalam terkait tren action figure yang berkembang saat ini, khususnya di Indonesia.

Data yang didapat kemudian akan diolah untuk disusun dalam beberapa kategori tema konten video yang kemudian akan dikembangkan kedalam storyboard. Dalam proses pengambilan video, set lokasi menggunakan studio indoor dan penggunaan beberapa titik pencahayaan yang diatur untuk menghasilkan tampilan video yang tidak membosankan. Dalam proses pascaproduksi, video akan ditambahkan dengan beberapa infografis, cuplikan video referensi dan beberapa footage yang memperlihatkan detail dari action figure untuk membantu penonton agar dapat lebih memahami informasi yang disampaikan.

\section{HASIL DAN PEMBAHASAN}

\section{YouTube Banner \& Bumper}

Menggunakan merek AIGO (Action-Figure-Info) sebagai identitas konten dengan tujuan untuk mendapatkan perhatian penonton ditengah banyaknya video sejenis yang ada di YouTube. Konsep logo menggunakan logotype yang memanfaatkan huruf sebagai logo itu sendiri. Konsep logotype ini menggunkan font Cooperblack yang di modifikasi sehingga menjadikan logo AIGO menjadi unik dan berbeda. 


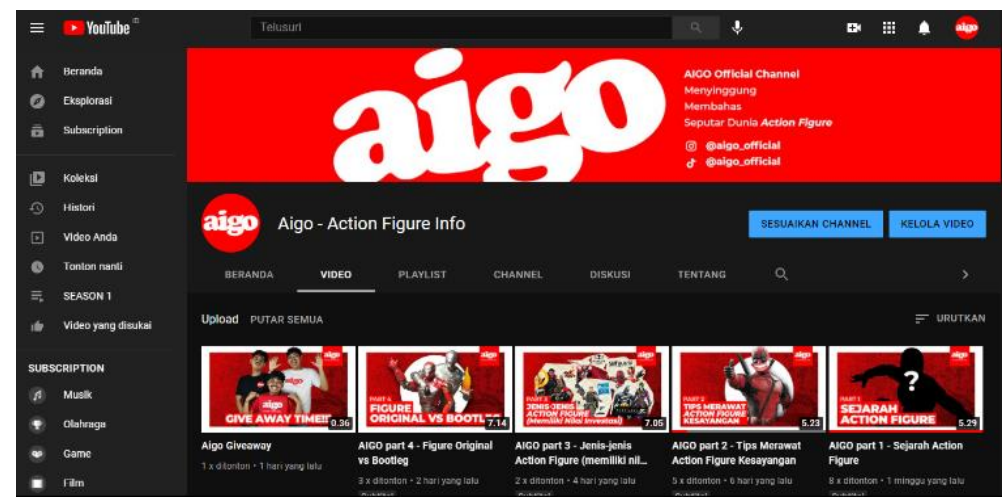

Gambar 1. Desain YouTube Banner

Identitas AIGO ini akan diterapkan kedalam YouTube banner dan animasi logo. Animasi logo ini memiliki ukuran rasio aspek 16:9 dengan ukuran frame 720p dan 24fps sehingga dapat dinikmati melalui layar gawai maupun laptop. Memiliki durasi 8 detik dan menjadi bumper untuk setiap video yang ditayangkan.

\section{Video}

Berupa video vlog yang berisikan infromasi-informasi seputar dunia action figure mulai dari sejarah, cara merawat, jenis-jenis figur, hingga perbedaan figur bootleg (palsu) dengan asli. Video terdiri dari 4 bagian yang berdurasi 5-7 menit dan satu video trailer yang berdurasi 58 detik dan memiliki resolusi 1920 x 1080px, dengan framerate hingga $24 \mathrm{fps}$.

Video bagian pertama membahas tentang sejarah terciptanya action figure untuk pertamakali. Didalam video ini menjelaskan siapa tokoh pertama yang mempopulerkan action figure ini dan bagaimana bentuk action figure pertama didunia. Video ini selain memberikan informasi awal terkait sejarah action figure juga berperan sebagai pembuka atau pengenalan awal terkait identitas merek kanal YouTube AIGO. 


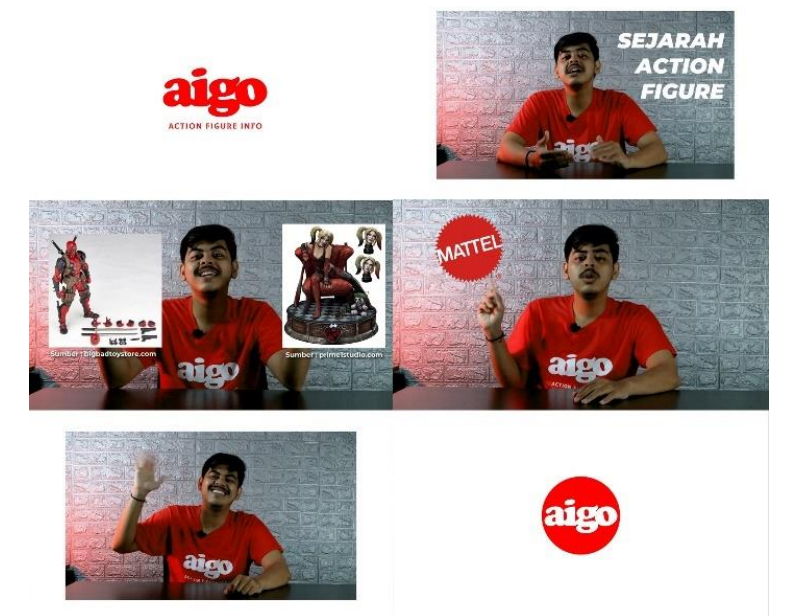

Gambar 2. Cuplikan Video Pertama

Berikutnya di video bagian kedua, menjelaskan tentang bagaimana cara merawat koleksi action figure kesayangan dan alat-alat apa saja yang dibutuhkan untuk membersihkan, merawat, serta menjaga koleksi kesayangan. Informasi, tips $\&$ trik dalam merawat dan menjaga action figure yang diberikan didapat dari hasil wawancara dengan narasumber, sehingga informasi yang diberikan lebih aktual dan jarang ditemui di forum maupun video serupa.

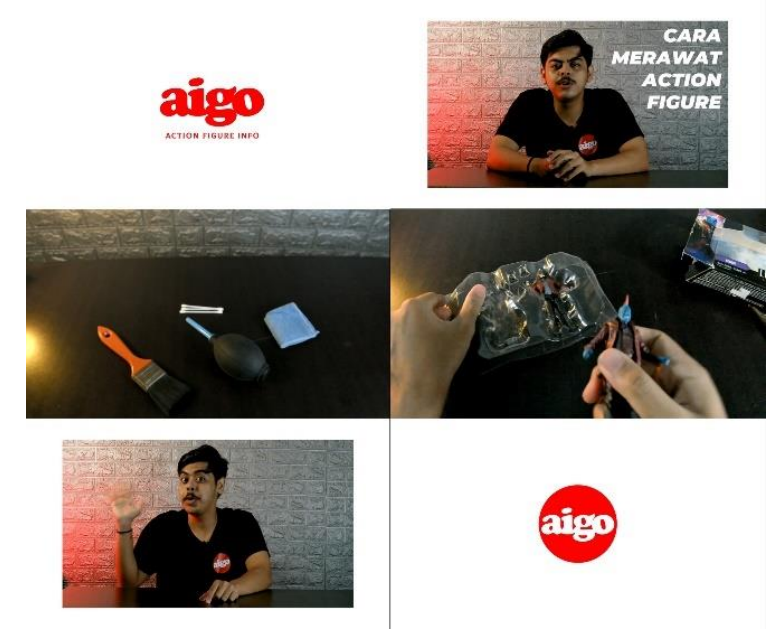

Gambar 3. Cuplikan Video Kedua 
Video bagian ketiga akan membahas tentang merek-merek action figure yang memiliki nilai investasi, serta informasi mengenai merek action figure yang banyak diminati kolektor untuk dijadikan investasi. Disajikan dengan menampilkan langsung bentuk action figure yang dimaksud untuk memberikan tampilan visual secara detail dan menunjukkan juga faktor-faktor yang menyebabkan action figure tersebut memiliki nilai investasi yang tinggi.

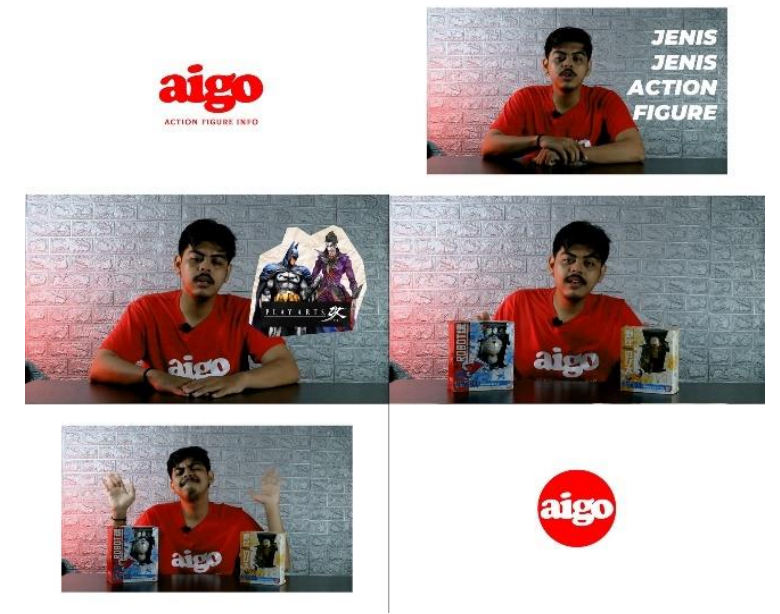

Gambar 4. Cuplikan Video Ketiga

Sebagai penutup musim pertama, video bagian keempat akan menampilkan perbedaan antara action figure bootleg (palsu) dengan original (asli). Disajikan dengan memberikan perbandingan langsung antara kedua jenis action figure tersebut, menjelaskan kelebihan serta kekurangannya dan menunjukkan detaildetail yang dapat diperhatikan ketika akan membeli action figure. Seluruh video vlog ini akan ditayangkan di YouTube dan Instagram sebagai media penunjang pemasarannya. 


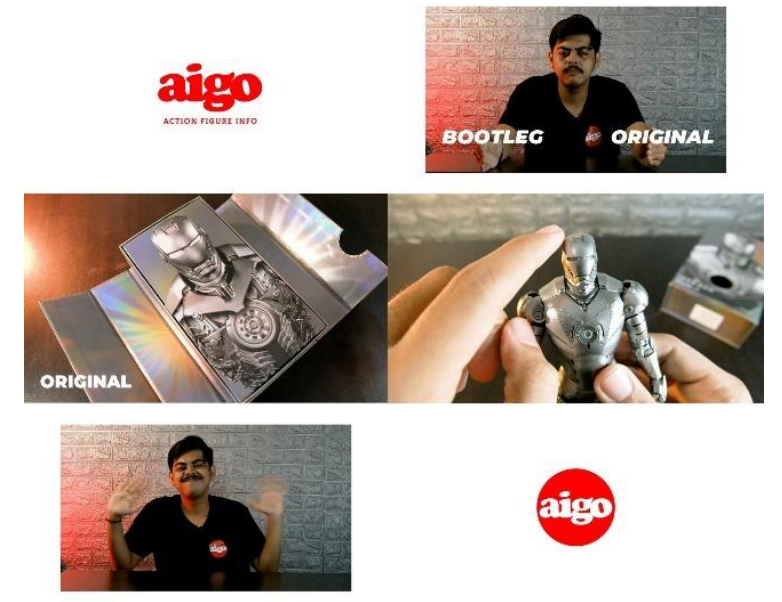

Gambar 5. Cuplikan Video Keempat

\section{Instagram}

Memiliki dimensi desain dengan ukuran 1080x1080px disetiap unggahannya dengan warna yang disesuaikan dengan logo dari AIGO yaitu merah dan putih. Konten yang diunggah terdiri dari cuplikan video yang sudah ditayangkan di YouTube, beberapa infografis seputar action figure yang didapat dari narasumber hingga acara atau kuis yang digunakan untuk berinteraksi langsung dengan pengikut akun Instagram dan YouTube AIGO.

Selain itu dengan memanfaatkan fitur Instastory dan Reels, AIGO dapat mempromosikan video yang akan ditayangkan selanjutnya, menunjukkan berbagai aktivitas terkait action figure kepada pengikut dan memberikan tayangan langsung kepada penonton di acara atau pameran terkait action figure. 


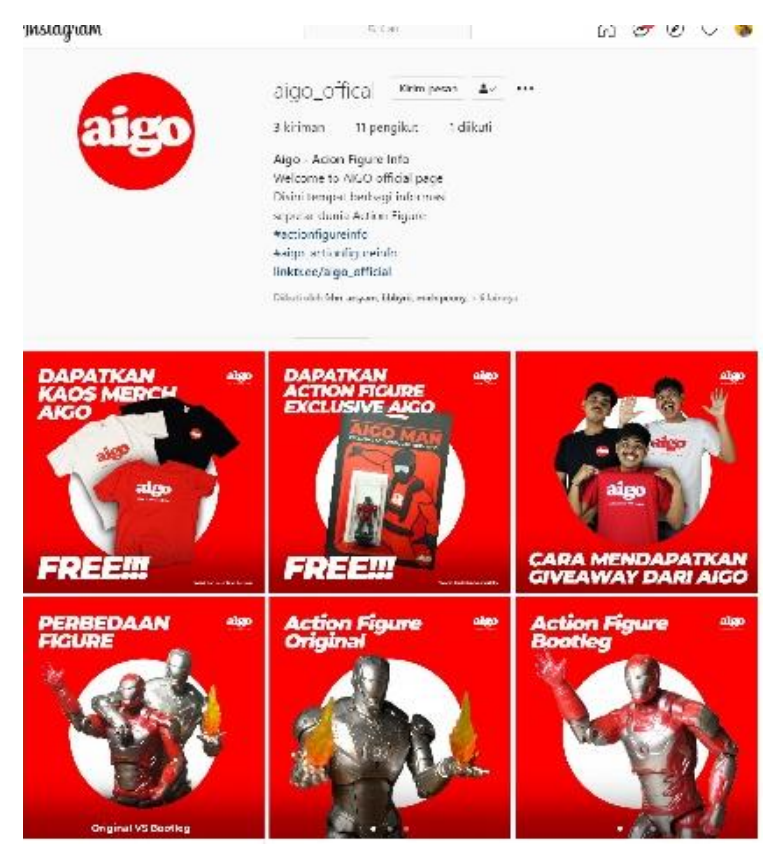

Gambar 6. Desain Tampilan Instagram

\section{Souvenir}

Souvenir selain digunakan sebagai hadiah untuk penonton, juga dapat digunakan sebagai media pendukung yang dapat memperkuat identitas merek AIGO di dalam lingkungan sekitar. Souvenir dapat diperoleh dengan cara mengikuti kuis atau tantangan yang diberikan di akhir video atau melalui unggahan di Instagram. Souvenir terdiri dari kaos, stiker,totebag hingga gantungan kunci.

Kaos menggunakan bahan soft-tee yang dimana memiliki kualitas yang lembut, sehingga ketika dikenakan tidak panas dan nyaman. Kaos memiliki varian warna yaitu hitam, merah, dan putih masing-masing diberi sablon dari logo AIGO yang menggunakan bahan plastisol yang memiliki sifat solid dan lentur. Kaos juga dapat menjadi media pemasaran karena dibagian belakang akan terdapat tautan yang mengarah ke situs YouTube. 


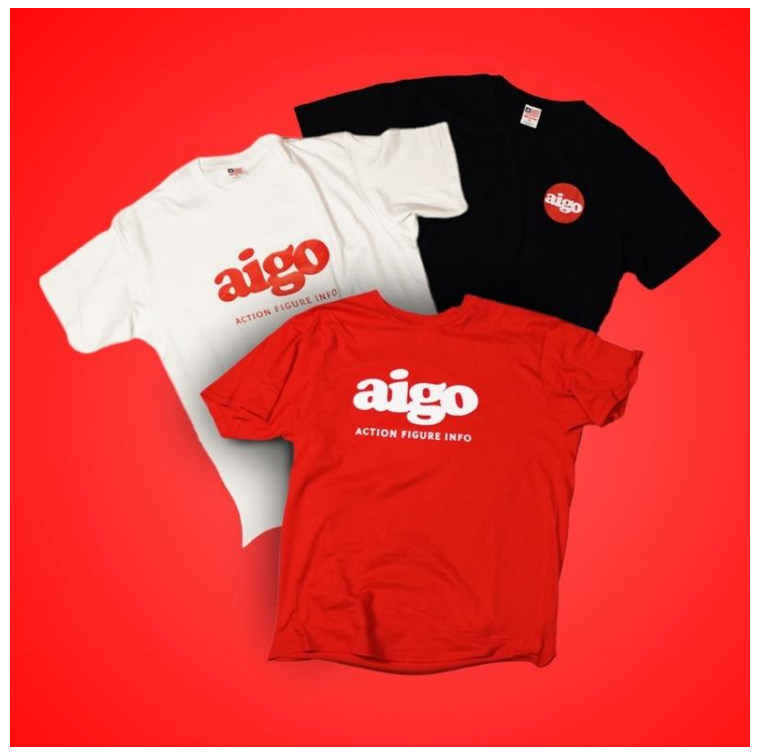

Gambar 7. Desain Kaos

Stiker Dibuat dengan bahan sticker vinyl susu dibagi menjadi 3 bentuk yang di ambil dari logo Aigo, dengan dimensi ukuran 4 x $6 \mathrm{~cm}$ dan 4 x 4cm. Stiker dapat diletakkan diberbagai jenis permukaan yang nantinya diharapkan dapat menguatkan identitas AIGO di tempat publik.

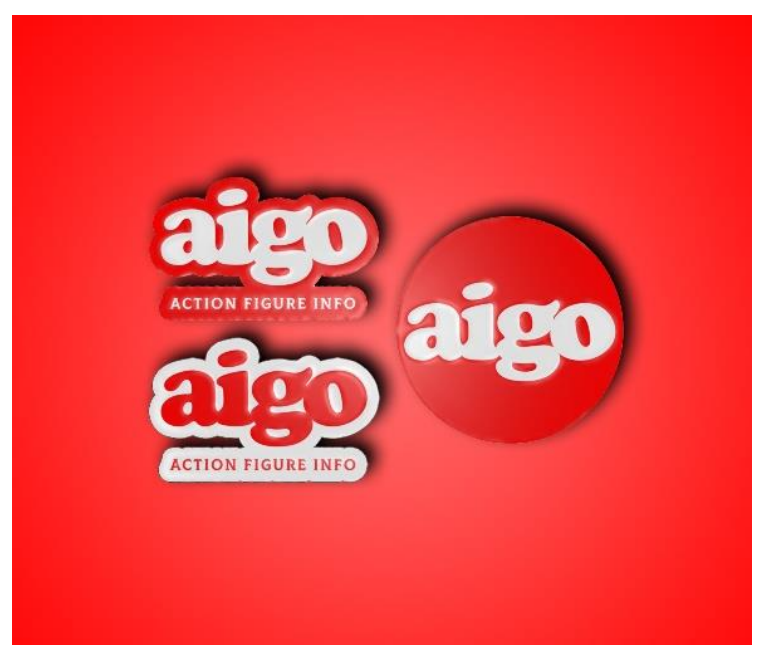

Gambar 8. Desain Stiker

Totebag AIGO ini nantinya menggunakan bahan kanvas berwarna hitam dengan ukuran A4, berfungsi untuk membawa barang-barang ketika bepergian. Selain itu bisa pula sebagai jinjingan untuk membawa berkas kantor, atau bisa juga 
dipakai sebagai tas oleh mahasiswa, ibu-ibu berbelanja keperluan dapur, atau aktivitas lainnya.

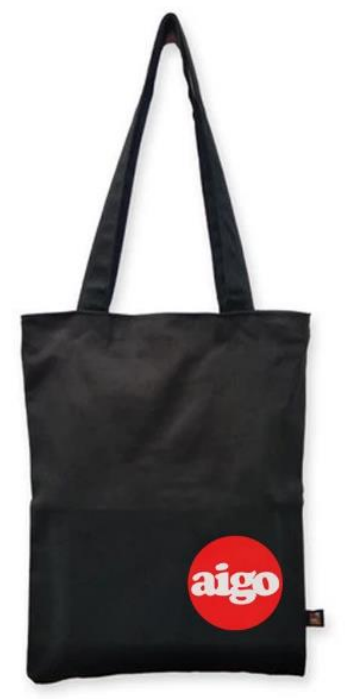

\section{Gambar 9. Desain Totebag}

Key chain atau gantungan kunci ini akan di sertakan dalam giveaway sebagai bonus. Memiliki dimensi ukuran 4 x $4 \mathrm{~cm}$ dan berbahan dasar acrylic. Gantungan kunci dapat memberikan nilai estetika kepada barang-barang tertentu dan gantungan kunci dapat diperoleh sebagai salahsatu hadiah yang diberikan disetiap kuis atau giveaway.

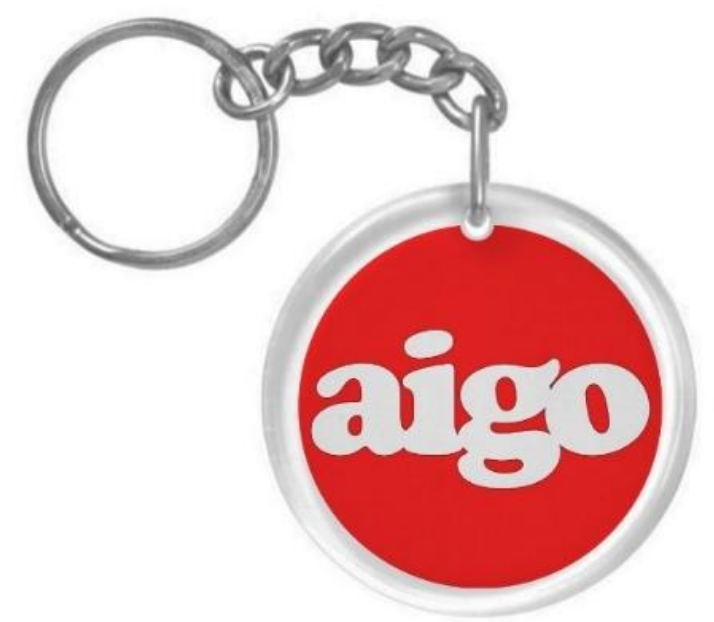

Gambar 10. Desain Gantungan Kunci 


\section{SIMPULAN DAN SARAN}

\section{Simpulan}

Melalui bentuk video vlog, AIGO secara efektif mampu memberikan informasi yang aktual dan dapat dengan mudah menjangkau audiens lebih luas. Mayoritas masyarakat saat ini yang sudah paham dengan teknologi digital menjadi salah satu penyebab mengapa bentuk media ini lebih efektif. Dengan menggunakan bentuk video YouTube, maka beberapa detail informasi dapat disajikan secara interaktif melalui narasi, infografis hingga tampilan langsung dari objek action figure yang dibahas sehingga audiens mendapatkan informasi yang lengkap dengan durasi yang tidak terlalu panjang. Selain itu dengan bentuk video YouTube ini, juga dapat disisipi dengan subtitle multi-bahasa untuk membantu penonton yang tuli maupun penonton dari luar Indonesia.

\section{Saran}

Selama proses perancangan ada beberapa hal yang perlu diperhatikan, khususnya dalam proses produksi. Karena setiap action figure yang dibahas cenderung memiliki nilai investasi, tentunya perlu diperhatikan terkait bagaimana merawat dan menjaga action figure tersebut selama proses produksi berjalan. Penataan pencahayaan juga perlu diperhatikan mengingat ukuran action figure cenderung kecil, maka cahaya yang digunakan sebaiknya jangan terlalu terang agar beberapa detail yang ada di action figure tersebut tidak tampak menyilaukan ketika direkam.

\section{DAFTAR PUSTAKA}

Action Figure Fury. 2014. Call to Action (Figures) - Why We Collect. Diakses pada tanggal 1 Desember 2021 dari https://www.actionfigurefury.com/callaction-figures-why-we-collect/

Databoks , Pusat Data Ekonomi dan Bisnis Indonesia. 2021. 94\% Orang Indonesia Akses YouTube dalam Satu Bulan Terakhir. Diakses pada tanggal 1 Desember 2021

dari https://databoks.katadata.co.id/datapublish/2021/02/17/94-orang-indonesiaakses-youtube-dalam-satu-bulan-terakhir

Junawan, Hendra, Nurdin Laugu. 2020. "Eksistensi Media Sosial,Youtube, Instagram dan Whatsapp Ditengah Pandemi Covid-19 Dikalangan Masyarakat Virtual Indonesia". Baitul Ulum: Jurnal Ilmu Perpustakaan dan Informasi. Vol. 4. No. 1. 2020. Hal. 41-57. 
Medcom. 2015. Membedakan Action Figure Palsu dan Orisinal. Diakses pada tanggal 11 Desember 2021 dari https://www.medcom.id/teknologi/poptech/DkqDJXQb-membedakanaction-figure-palsu-dan-orisinal

Priyono. 2008. Metode Penelitian Kuantitatif. Zifatama Publishing. Sidoarjo.

Putra, Edi Setiadi. 2010. Perancangan Media Action Figure untuk Representasi Budaya Studi Kasus: Artefak Vernakular Sunda. Laporan Penelitian. Itenas. Bandung.

Raco, J.R. 2010. Metode Penelitian Kualitatif. Grasindo. Jakarta.

Widada, Sugeng. 2019. Teknik Dasar Menggunakan Videografi di Dunia Broadcasting. eJournal Raharja. STMIK Raharja. Tanggerang. 